\title{
Differential effects of frozen storage on the molecular detection of bacterial taxa that inhabit the nasopharynx
}

\author{
Brenda A Kwambana ${ }^{1,2}$, Nuredin I Mohammed', David Jeffries' ${ }^{1}$, Mike Barer², Richard A Adegbola ${ }^{1,3}$, \\ Martin Antonio ${ }^{1 *}$
}

\begin{abstract}
Background: Frozen storage often precedes metagenomic analysis of biological samples; however, the freezing process can have adverse effects on microbial composition. The effect of freezing on the detection of bacteria inhabiting the infant nasopharynx, a major reservoir of bacterial pathogens, was investigated.

Methods: $16 \mathrm{~S}$ ribosomal RNA (rRNA) gene-based terminal restriction fragment length polymorphism (T-RFLP) analysis of nasopharyngeal (NP) swabs from twelve Gambian infants was employed. NP swabs were analysed within hours of collection and then after 30 days of storage at $-70^{\circ} \mathrm{C}$.
\end{abstract}

Results: There was substantial heterogeneity among subjects with respect to the effect of freezing on the number of operational taxonomic units (OTUs) detected. Nevertheless, the mean number of OTUs decreased after frozen storage and the relative abundance for $72 \%$ of the OTUs changed by less than $0.5 \%$ after deep frozen storage. There were differences in the odds of detection and relative abundance of OTUs matched with Moraxella sp., Haemophilus sp./Burkholderia sp., and Pseudomonas sp. A strong interaction between sex and the effect of freezing was found, whereby there was no significant change observed for males while the mean number of OTUs significantly declined among female infants following frozen storage.

Conclusions: Although frozen storage of biological samples is often necessary for archiving and logistic purposes, the potential effects on the number of taxa (composition) detected in microbial community studies are significant and should not be overlooked. Moreover, genetic factors such as sex may influence the integrity of nucleic acids during the freezing process.

\section{Background}

Nasopharyngeal swabbing is an important diagnostic and epidemiological surveillance tool used to detect several pathogens in one of the most clinically relevant microbial reservoirs in the human body [1,2]. Although detection of microbes in nasopharyngeal (NP) swabs stored in skim milk-tryptone-glucose-glycerin (STGG) is often employed in epidemiology and diagnostic research [3], few studies have investigated the potential bias introduced during sample storage, which usually involves deep freezing at $-20^{\circ} \mathrm{C}$ or $-70^{\circ} \mathrm{C}[1,4-6]$.

\footnotetext{
* Correspondence: mantonio@mrc.gm

'Bacterial Diseases Programme, Medical Research Council Laboratories (UK), Banjul, The Gambia

Full list of author information is available at the end of the article
}

Furthermore, these studies have focused on the effects of frozen storage on the culture-based detection of specific pathogens such as Streptococcus pneumoniae. However, the impact of freezing on the molecular culture-independent detection of the microbial communities inhabiting the nasopharynx is yet to be fully understood.

With the widespread application of vaccines and antibiotics against respiratory pathogens, serotype and species replacement is becoming increasingly important. The occurrence of species replacement depends on the ecological events that occur during the replenishment of the niche left vacant following vaccination or antibiotic treatment. Hence, extensive microbial ecology studies will be necessary to fully understand these events and

\section{Ciomed Central}


identify microbes that play a significant role in replenishment. Furthermore, the competitive relations between bacterial types inhabiting the nasopharynx which may alter predisposition to disease will be elucidated by broad comparative community analyses. This reinforces the need to broaden the scope of upper airway microbiology studies [7-10]. However, only a small fraction of bacterial composition can be cultivated by standard laboratory techniques $[11,12]$. Hence, culture-dependent applications grossly underestimate species richness, relative abundance and composition, limiting their utility in the comprehensive analysis of microbial communities [13]. To address various aspects of diverse microbial communities, microbiologists have employed an extensive array of culture-independent molecular tools which are often based on PCR and target the rRNA gene cluster $[14,15]$. Although molecular tools avert considerable bias introduced by selective cultivation and have revolutionized our understanding of microbial ecology, they also have several limitations. Common to all PCR-based applications are several pitfalls which can occur at every stage of sample processing [13]. Bias can be introduced during sample collection and transport, sample storage, cell lysis, nucleic acid extraction, PCR amplification, and other downstream applications [13,16-20]. One of the advantages of molecular applications is that samples can be stored and analysed even after the loss of viability of microbial cells. For logistic and technical reasons, frozen storage often precedes the molecular analysis of biological samples. However, it is becoming increasingly evident that the deep freezing process can have adverse effects on microbial composition and the detection of specific bacterial strains $[4,21,22]$.

Prior to a study characterizing the development of the infant nasopharyngeal microbiome, we set out to validate an effect of frozen storage of NP swabs on the molecular detection of bacterial taxa using $16 \mathrm{~S}$ rDNA based-Terminal restriction fragment length polymorphism (T-RFLP). T-RFLP is a PCR based DNA fingerprinting tool that has been applied in community analyses across different ecosystems [23]. To our knowledge this is the first investigation of an effect of freezing on the $16 \mathrm{~S}$ rRNA gene-based profiling of microbial communities of the infant nasopharynx.

\section{Methods}

\section{Study site and sample collection}

On the same day, a nasopharyngeal swab was collected from each of twelve Gambian infants (5 male and 7 female). Infants were recruited from the Western Region with parental informed consent as previously described by Hill et al., 2008 [24]. The study was approved by the Medical Research Council Scientific Coordinating Committee and Joint Gambian Government Ethics
Committee. Trained field nurses used sterile calcium alginate fibre tipped swabs with aluminium shafts (Fisher brand $^{\circledR}$, USA), which were immediately placed in $1 \mathrm{~mL}$ of STGG medium, kept on ice and transported to the laboratory within 4 hours of collection as previously described. At the time of sampling six infants were 16 weeks old and six were 26 weeks old. Subject data is summarized in Table 1.

\section{DNA Extraction}

Duplicate nucleic acid extractions were carried out for each of the twelve NP swabs prior to and post freezing, giving a total of 48 purified DNA samples. $100 \mu \mathrm{L}$ of each NP swab were extracted using the UltraClean ${ }^{\circledR}$ Microbial DNA Isolation Kit (Mo-Bio, USA) following manufacturer's protocol. For direct analysis, DNA was extracted from NP swabs kept on ice within 4 hours of collection. For frozen analysis, DNA was extracted from the NP swabs frozen at $-70^{\circ} \mathrm{C}$ for 30 days and gently thawed on ice. DNA was eluted in $50 \mu \mathrm{L}$ of elution buffer (MD5) and stored at $-20^{\circ} \mathrm{C}$. Duplicate extractions were carried out for both fresh and frozen analyses to control for variability associated with the extraction process.

\section{PCR for T-RFLP Analysis}

The PCR was optimized to produce minimal amounts of primer dimer which can interfere with T-RFLP analysis. $16 \mathrm{~S}$ rDNA amplification yielding fragments $\sim 700 \mathrm{bp}$ was performed in $25 \mu \mathrm{L}$ reaction volumes consisting of $2.5 \mu \mathrm{L}$ of DNA, 1x Green GoTaq reaction buffer with $1.5 \mathrm{mM} \mathrm{MgCl}_{2}$, 1.0 U GoTaq Polymerase (Promega, $\mathrm{UK}$ ), each deoxynucleoside triphosphate at $0.2 \mathrm{mM}$ of each deoxynucleoside triphosphate (dNTP) (QIAGEN, $\mathrm{UK}), 0.5 \mu \mathrm{M}$ of 6-carboxyfluorescein labelled forward primer 338F-[ 6-FAM] (5'-ACT CCT ACG GGN GGC NGC A-3') (Applied Biosystems, UK) and $0.25 \mu \mathrm{M}$ 1046R (5'-CAC GAG CTG ACG ACA NCC ATG CAN CAC C-3'). Amplification was carried out by initial denaturation of $94^{\circ} \mathrm{C}$ for 1 minute, followed by 30 cycles of denaturation at $94^{\circ} \mathrm{C}$ for 1 minute, annealing at $58^{\circ} \mathrm{C}$ for 1 minute, and extension at $72^{\circ} \mathrm{C}$ for 2 minutes. Final extension was done at $72^{\circ} \mathrm{C}$ for 10 minutes. Duplicate PCR products were pooled and purified with the QIAquick PCR Purification Kit (QIAGEN, UK) and stored at $-20^{\circ} \mathrm{C}$. PCR products were checked by $1.5 \%$ agarose gel electrophoresis and PCR products were quantified by NanoDrop spectrophotometer. Duplicate amplifications were done for each DNA sample and pooled to reduce bias associated with PCR.

\section{T-RFLP Analysis}

Approximately $100 \mathrm{ng}$ of DNA were digested with $5 \mathrm{U}$ of restriction enzyme AluI (NEB, UK) for 3 hours at $37^{\circ} \mathrm{C}$, 
Table 1 Description of samples collected for this study

\begin{tabular}{lllllllllll}
\hline Subject & Sex & $\begin{array}{l}\text { NP Swabs } \\
\text { Collected }\end{array}$ & $\begin{array}{l}\text { Fresh DNA } \\
\text { Extractions }\end{array}$ & $\begin{array}{l}\text { Frozen } \\
\text { Storage }\end{array}$ & $\begin{array}{l}\text { Frozen DNA } \\
\text { Extractions }\end{array}$ & $\begin{array}{l}\text { Age at } \\
\text { Collection } \\
\text { (Weeks) }\end{array}$ & $\begin{array}{l}\text { Before } \\
\text { Frozen } \\
\text { Storage }\end{array}$ & $\begin{array}{l}95 \% \mathrm{Cl} \\
\text { (Poisson) }\end{array}$ & $\begin{array}{l}\text { After Frozen } \\
\text { Storage }\end{array}$ & $\begin{array}{l}95 \% \mathrm{Cl} \\
\text { (Poisson) }\end{array}$ \\
\hline 1 & M & 1 & 2 & 30 days & 2 & 16.9 & 12.0 & $7.7: 17.9$ & 14.5 & $9.7: 20.8$ \\
2 & M & 1 & 2 & 30 days & 2 & 16.6 & 3.5 & $1.4: 7.2$ & 11.5 & $7.3: 17.3$ \\
3 & F & 1 & 2 & 30 days & 2 & 16.4 & 8.0 & $4.6: 13.0$ & 1.5 & $0.3: 4.4$ \\
4 & F & 1 & 2 & 30 days & 2 & 16.1 & 13.5 & $8.9: 19.6$ & 0 & 0.1 .8 \\
5 & F & 1 & 2 & 30 days & 2 & 16.1 & 9.5 & $5.7: 14.8$ & 0 & $0.1 .8 *$ \\
6 & F & 1 & 2 & 30 days & 2 & 16.0 & 10.0 & $6.1: 15.4$ & 1.0 & $0.1: 3.6$ \\
7 & M & 1 & 2 & 30 days & 2 & 26.6 & 6.5 & $3.5: 11.1$ & 3.5 & $1.4: 7.2$ \\
8 & F & 1 & 2 & 30 days & 2 & 26.6 & 3.5 & $1.4: 7.2$ & 5.5 & $2.7: 9.8$ \\
9 & F & 1 & 2 & 30 days & 2 & 26.3 & 6.5 & $3.5: 11.1$ & 5.0 & $2.4: 9.2$ \\
10 & F & 1 & 2 & 30 days & 2 & 25.9 & 10.0 & $6.1: 15.4$ & 9.0 & $5.3: 14.2$ \\
11 & M & 1 & 2 & 30 days & 2 & 26.1 & 14.0 & $9.3: 20.2$ & 12.0 & $7.7: 17.9$ \\
12 & M & 1 & 2 & 30 days & 2 & 26.1 & 11.5 & $7.3: 17.3$ & 12.0 & $7.7: 17.9$ \\
\hline
\end{tabular}

$(*)$ one-sided, $97.5 \%$ confidence interval $(\mathrm{Cl})$.

followed by 20 minutes at $65^{\circ} \mathrm{C}$. Approximately equal amounts of PCR product from each sample were analysed to reduce the effects of fingerprinting different amounts of DNA. Digested amplicons were cleaned using SureClean (Bioline, UK) and eluted in $10 \mu \mathrm{L}$ $10 \mathrm{mM}$ Tris-Cl, pH 8.5 (QIAGEN, UK). $1 \mu \mathrm{L}(\sim 10 \mathrm{ng}$ ) of purified digest, $0.5 \mu \mathrm{L}$ of GeneScan-600 Liz and $8.5 \mu \mathrm{L}$ of $\mathrm{Hi}-\mathrm{Di}^{\mathrm{TM}}$ formamide (Applied Biosystems, UK) were mixed followed by DNA denaturation at $95^{\circ} \mathrm{C}$ for 3 minutes. Fragments were separated by size by capillary electrophoresis on a $3130 x l$ Genetic Analyzer (Applied Biosystems, UK) and visualized by excitation of the 6-FAM labelled attached to the 5 ' terminal fragment by the following protocol: Oven temperature $60^{\circ} \mathrm{C}$, injection voltage $1.6 \mathrm{kV}$, injection time $15 \mathrm{~s}$, running voltage $15 \mathrm{kV}$ and running time $2,500 \mathrm{~s}$.

\section{Reference nasopharyngeal bacteria library}

DNA extracts of NP swabs collected from 6 infants were used as template for the amplification of 16S rRNA fragments, using unlabelled universal primers 338F and 1046R as described above. Purified $16 \mathrm{~S}$ rDNA fragments were directly cloned using the pGEM $^{\circledR}$-TEasy Vector System following manufacturers protocol (Promega, UK). Putative positive colonies were selected by blue-white screening and cultured overnight in $100 \mu \mathrm{g} / \mathrm{mL}$ ampicillin LB broth. Inserts were amplified and sequenced using M13/pUC primers M13/pUCF (5'CCCAGTCACGACGTTGTA AAACG-3'), M13/pUCR (5' AGCGGATAACAA TTTCACACAGG-3'), (Promega, UK) following manufacturers protocol. Raw sequences were edited using Lasergene SeqMan (DNASTAR, UK). In silico digest of sequences was carried out using WebCutter 2.0 (http://rna.lundberg.gu. se/cutter2/) and matched with corresponding T-RFs. Sequences were screened for the presence of chimeras with the Mallard chimera-checking tool prior to submission. 165 partial 16S rRNA gene nucleotide sequences were deposited onto GenBank http://www.ncbi. nlm.nih.gov/Genbank and assigned accession numbers (HM179296 to HM179460).

\section{T-RFLP Statistical Analysis}

The electropherograms were analysed with GeneMapper ${ }^{\circledR}$ Software v4.0 (Applied Biosystems). The advanced peak detection algorithm was used and fragment sizes were determined by the Local Southern method and fluorescence signal was normalized for all the samples analysed. A fixed detection threshold of 100 fluorescence units (FU) was used to reduce inclusion of noise peaks in the analysis $[23,25]$. Terminal restriction fragments (T-RFs) that differed by \pm 1 bp in different profiles were binned in the same OTU. T-RFs between $50 \mathrm{bp}$ and $600 \mathrm{bp}$ were considered in the analysis to obtain 5' terminal fragments within the linear range of GS-600Liz (Applied Biosystems). Composition was calculated as the total number of distinct OTUs detected in a sample. The relative abundance of each OTU was determined by expressing the fluorescence units as a proportion of the sum of relative fluorescence signal for each sample [26]. A random effects model allowing for the within subject correlation was used to investigate the effect of freezing on composition and total RFUs per subject adjusting for age and sex. A random effects logistic regression model was used to study the association of detection of each OTU with the type of sample (frozen versus fresh) adjusting for age and sex where appropriate. Only OTUs detected in both primary and frozen samples were included and correction for multiple testing was done using Holm's method.

\section{Results}

Duplicate NP DNA extracts from each of the twelve infants were analysed within hours of collection and 
after thirty days of frozen storage at $-70^{\circ} \mathrm{C}$ in STGG. Hence, a total of 48 nucleic acid samples were analysed by $16 \mathrm{~S}$ rDNA T-RFLP (Table 1). Terminal restriction fragments (T-RFs) were not generated for seven samples, six frozen and one fresh sample due to poor amplification. Hence, $96 \%$ and $75 \%$ of samples analysed fresh and after frozen storage were successfully analysed by T-RFLP respectively. A total of 42 distinct OTUs were detected in the NP swabs, $86 \%, 74 \%$, and $62 \%$ were detected in fresh analysis only, after frozen storage only and in both analyses respectively.

Bacterial composition in frozen and fresh analysis was measured by the total number of distinct OTUs detected from NP swabs before and after freezing, which ranged from 0 to 15 OTUs per sample. The mean number of OTUs was 6.3 per sample for analysis post freezing and 9.0 per sample for fresh analysis. Results from a random effects model showed that there was a significant association between subjects and the effect of frozen storage on composition $(\mathrm{p}=0.0083)$. The model also indicated significant interaction between the sex of the subject and the effect of freezing on composition. Before freezing the mean number of OTUs for males and females were quite close, 9.5 and 8.7 respectively, however after freezing these were 10.7 and 3.1 respectively, see Figure 1. The difference in composition pre and post freezing was significant for female ( $\mathrm{p}$ $=0.0014)$ but not for male infants $(\mathrm{p}=0.56)$.

The effect of freezing NP swabs on the odds of detecting bacterial OTUs was analysed using a random effects logistic regression model, adjusting for sex. The odds of detecting most OTUs did not change with freezing; however, the detection of four taxa was significantly reduced at the $5 \%$ level by freezing, see Table 2 . Bioinformatics analysis of these T-RFs based on fragment size matched them with specific bacterial taxa as follows; Firmicutes (91 bp), Pseudomonas sp (309 bp), Moraxellaceae (147 bp), and Haemophilus sp/Burkholderia sp. (518 bp) (see Table 1). After correcting p-values for multiple testing using Holm's method none remained significant, thus the results should be interpreted with caution.

The effect of freezing on the relative abundance of OTUs was investigated. For more than $70 \%$ of the OTUs, there was less than a $0.5 \%$ change in relative abundance after freezing, see Figure 2. 28\% of the OTUs had $0.6 \%$ to $18.6 \%$ shifts in relative abundance post frozen storage, with half showing an increase and the other half showing a decrease in relative abundance. The relative distributions of OTUs were compared for male and female infants as well as before and after freezing, see Figure 3. The relative distributions of bacterial taxa were comparable between male and female infants as well as before and after freezing. The relative proportions of some major taxonomic groups including Haemophilus sp., Staphylococcus sp. Moraxella sp., and Firmicutes were comparable before and after freezing for both sexes, see Figure 3. However, the relative proportions of some OTUs including the OTU $392 \mathrm{bp}$, the $309 \mathrm{bp}$ OTU (Pseudomonas $s p$ ), the 216 bp OTU (Rothia $s p$ ), the 278 bp OTU (Acinetobacter sp.) and OTUs with relative abundance less than $1 \%$ showed some change before and after freezing amongst the infants.

\section{Discussion}

We report preliminary data showing that deep freezing NP swabs in STGG medium at $-70^{\circ} \mathrm{C}$ may have a modest effect on the fingerprint of bacterial communities and a differential effect on the detection of bacterial OTUs found in the infant nasopharynx. Although the relative proportions of some OTUs changed, overall, the relative distributions were comparable before and after frozen storage (Figure 3). Previous studies which investigated the effects of frozen storage on the detection of various microbes in biological samples have shown minimal or no significant effects [1,21,27-29]. Abdullahi et al. (2007) reported that the recovery of S. pneumoniae from fresh and frozen NP swabs in STGG was consistent, but there were differences in the serotype distributions [21]. This could be attributed to a differential capacity to survive the freezing process among S. pneumoniae serotypes. In another culture-based study, there was no effect of freezing on the recovery of $S$. pneumoniae and $S$. aureus from milk samples frozen at $-20^{\circ} \mathrm{C}[27,28]$, but there was an increase in the detection of coagulase negative staphylococci and a decrease in the recovery of Escherichia coli and Actinomyces pyogenes [28]. Likewise, a recent $16 \mathrm{~S}$ rRNA gene-based study of Black Band Disease showed that frozen storage increased the proportion of Proteobacteria phylotypes while direct analysis promoted the detection of cyanobacterial and sulfur-oxidizing bacteria [22].

These reports suggest that there may be differential survival capacities to frozen storage among bacterial taxa from the same community. As such, the deep freezing and thawing processes may alter the odds of detection and relative abundance of some, but not all OTUs in a biological sample. In this study, frozen storage significantly altered the odds of detecting a small proportion $(<10 \%)$ of the bacterial OTUs found (Table 1$)$ and the relative abundance of a couple of OTUs changed by more than $5 \%$ after frozen storage (Figure 2). This could be explained by DNA degradation amongst some bacterial taxa; Suomalainen and colleagues demonstrated that the freezing process results in the disintegration of the Flavobacterium columnare cell wall, associated with the release of large quantities of DNAse, lysases and proteases [4]. There is further evidence that the structure 


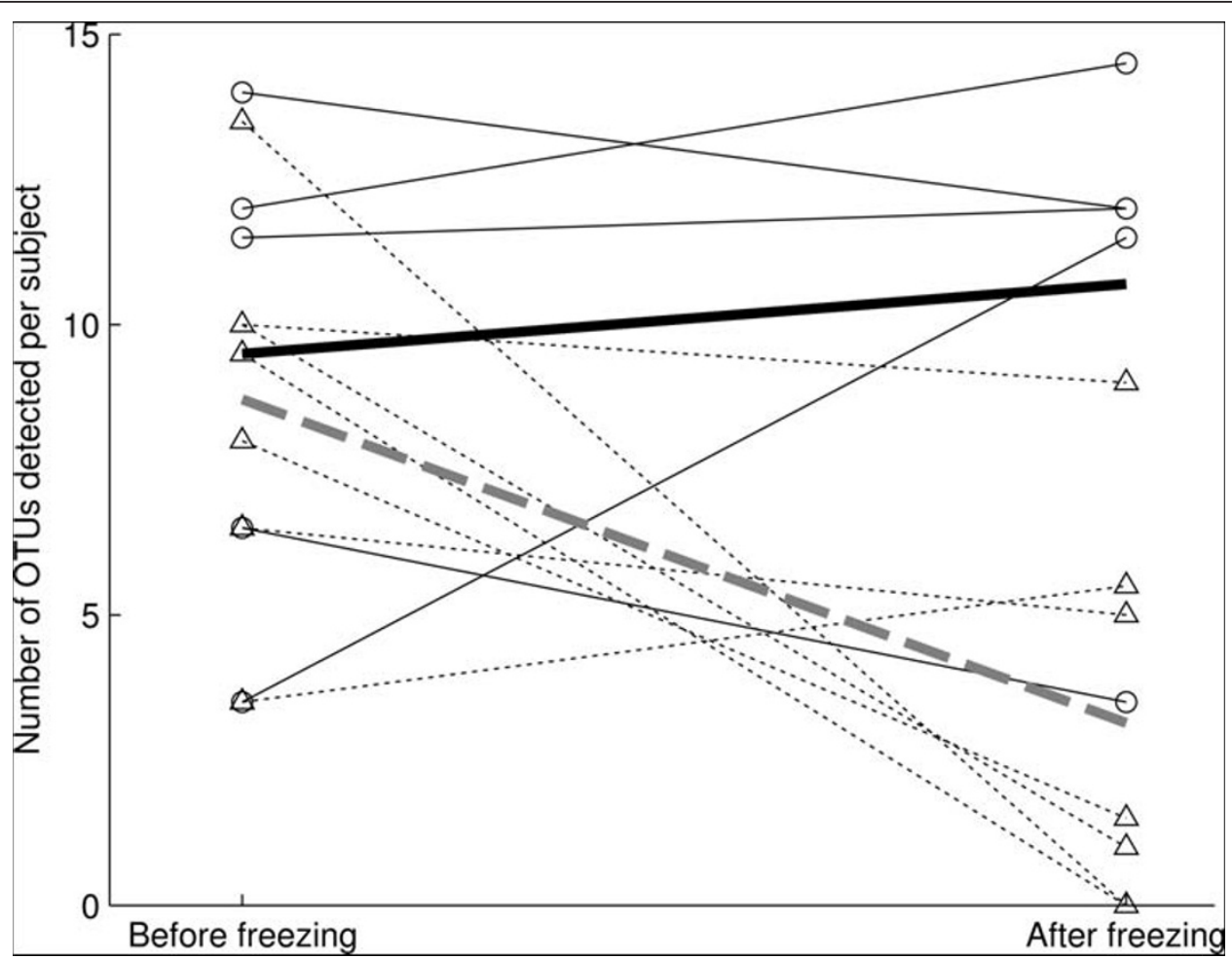

Figure 1 Effect of frozen storage on the composition of bacterial OTUs found in the infant nasopharynx. The composition (mean number of OTUs) per subject against $16 \mathrm{~S}$ rRNA-based T-RFLP before and after freezing at $-70^{\circ} \mathrm{C}$ dichotomized by sex. Dotted lines represent females, and the bold dotted line shows the mean change. The difference in composition pre and post freezing was significant for female $(p=$ $0.0014)$ but not for male infants $(p=0.56)$.

Table 2 Effect of frozen storage on the detection of bacterial OTUs by 16S rRNA-based T-RFLP

\begin{tabular}{lllll}
\hline OTU (bp) & Log odds of detection & $\mathbf{p}$ value & $\mathbf{9 5 \%} \mathbf{C l}$ & Closest Bacterial Match (>97\% Sequence Similarity) \\
\hline 87 & 1.81 & 0.25 & $-1.25,4.86$ & \\
$\mathbf{9 1}$ & $-\mathbf{3 . 0 4}$ & $\mathbf{0 . 0 1}$ & $\mathbf{- 5 . 4 3 , - 0 . 6 5}$ & Firmicutes \\
$\mathbf{1 1 4}$ & $\mathbf{- 2 . 0 0}$ & $\mathbf{0 . 0 4}$ & $\mathbf{- 3 . 9 5 , - 0 . 0 5}$ & Moraxella sp. \\
116 & $2.63^{*}$ & 0.36 & $-2.96,8.22$ & Marinomonas $s p$. \\
133,215 & $2.63^{*}$ & 0.36 & $-2.96,8.22$ & \\
155 & 1.34 & 0.20 & $-0.69,3.38$ & \\
216 & -1.18 & 0.15 & $-2.80,0.43$ & Corynebacterium propinquum, Rothia mucilaginosa \\
273 & -2.44 & 0.26 & $-6.66,1.79$ & Flavobacteriaceae \\
294 & $0.94^{*}$ & 0.52 & $-1.89,3.76$ & \\
$\mathbf{3 0 9}$ & $-\mathbf{2 . 7 7}$ & $\mathbf{0 . 0 3}$ & $\mathbf{- 5 . 3 4 , - 0 . 2 1}$ & Pseudomonas sp. \\
392 & -2.21 & 0.06 & $-4.52,0.11$ & \\
492 & -0.67 & 0.57 & $-2.99,1.66$ & Clostridiales Incertae Sedis XI \\
502 & $2.63^{*}$ & 0.36 & $-2.96,8.22$ & \\
504 & -2.39 & 0.25 & $-6.49,1.70$ & Haemophilus influenzae \\
$\mathbf{5 1 8}$ & $-\mathbf{2 . 5 9}$ & $\mathbf{0 . 0 1}$ & $\mathbf{- 4 . 5 8 , - 0 . 6 1}$ & Haemophilus influenzae, Burkholderia fungorum, Comamonadaceae \\
520 & -0.36 & 0.68 & $-2.02,1.31$ & Staphylococcus sp. \\
521 & -1.70 & 0.11 & $-3.80,0.40$ & \\
\hline
\end{tabular}

A random effects logistic regression model adjusting for sex was used. ${ }^{*}$ Indicates OTUs for which sex adjustment was not done. Bold indicates significant results at the $5 \%$ level after correcting for multiple testing using Holm's method none of them appeared significant. 


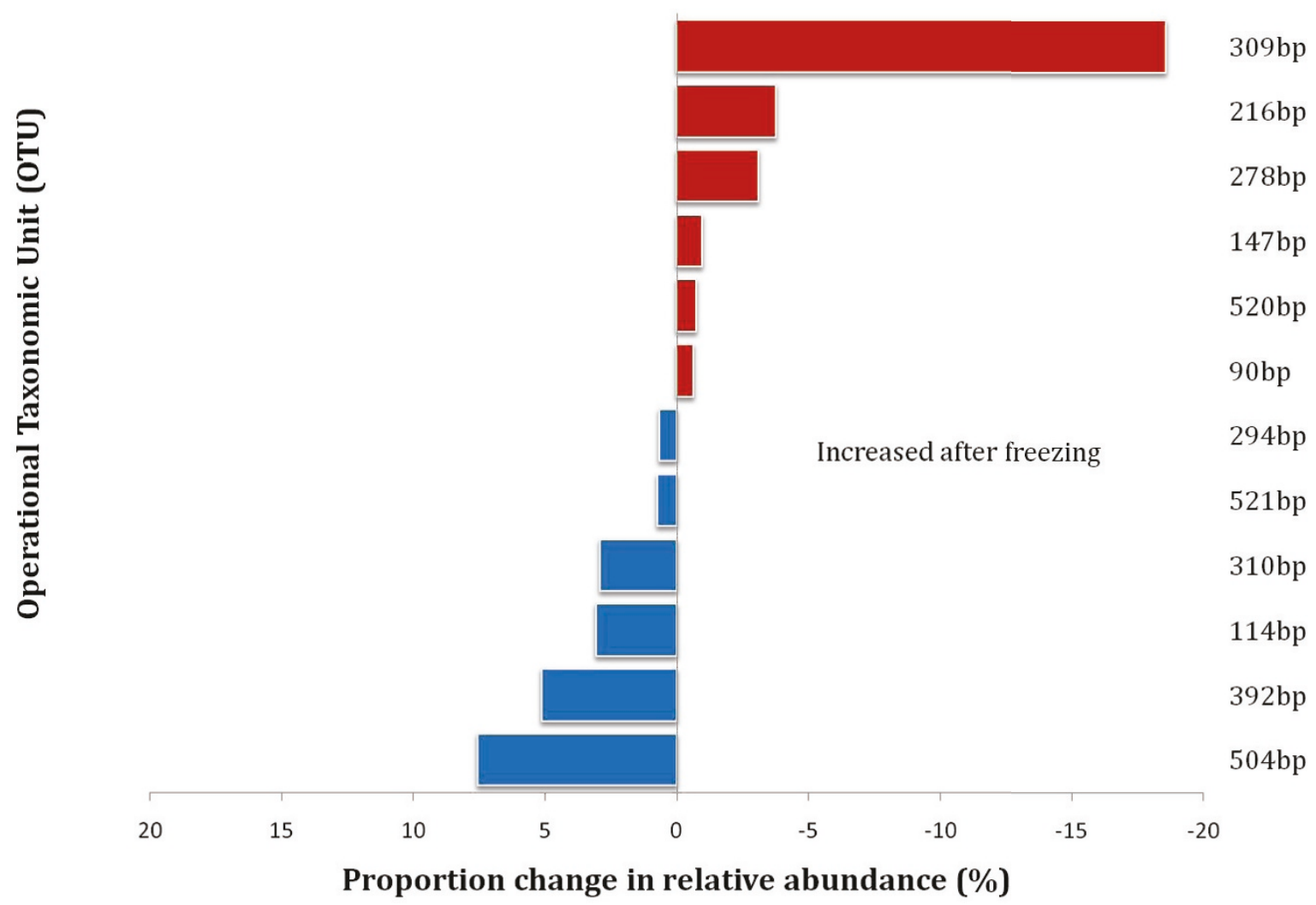

Figure 2 Bar graph showing proportion change in relative abundance of bacterial OTUs after frozen storage of NP swabs at $-70^{\circ} \mathrm{C}$ analysed by $16 \mathrm{~S}$ rRNA T-RFLP. The difference in relative abundance before and after frozen storage was expressed as a proportion of the relative abundance for direct analysis. Most of the 42 OTUs detected showed minimal $(<0.5 \%)$ change and OTUs that had proportion change $>0.5 \%$ are shown here.

and stability of bacterial cells influence cryo-preservation of nucleic acids [30].

Interestingly, the observed decrease in the number of OTUs found after frozen storage was significant among female $(\mathrm{p}=0.0014)$ but not among male infants $(\mathrm{p}=$ $0.56)$ (Figure 1). This preliminary data suggests that an effect of freezing on microbial detection may also be differential across sexes. Interestingly, several OTUs detected in both sexes in fresh NP swabs were not detected or were detected at much lower frequencies among female infants post frozen storage. Although sex has been shown to be an important factor in colonization by various bacterial pathogens [31,32], this finding has not been reported elsewhere to our knowledge. It is unclear how an effect of deep freezing on bacterial detection could be differential depending on the sex of a subject, which necessitates further investigations.

Frozen storage of biological samples is necessary for archiving and often done for logistic purposes where real-time processing of samples is not practicable. With the widespread use of vaccines targeting commensals of the respiratory mucosae, it is essential to effectively monitor non-vaccine serotypes and species replacement disease $[33,34]$. Tracking intra-species serotype replacement and/or switching has overshadowed comprehensive research into the long term effects of vaccination on the microbiome, which may influence health, predisposition to disease and the pathogenesis of various infections $[35,36]$. Loss or increased detection of particular taxa due to deep frozen storage may have a bearing on microbial ecology and species replacement surveillance. Furthermore, the intricate competitive relations between bacterial phylotypes may not be fully understood if deep freezing alters the fingerprint of microbial communities, albeit modestly [7-10].

In this study, we investigated the effect of frozen storage on NP swabs stored in STGG from 12 infants. However, the sample size and study design limit the validity of the findings. Broad investigations of different biological specimens, storage media, storage duration and microbial detection tools are needed to validate these findings. An effect of frozen storage on microbial detection using culture-based and culture-independent approaches needs to be studied. Finally, further 


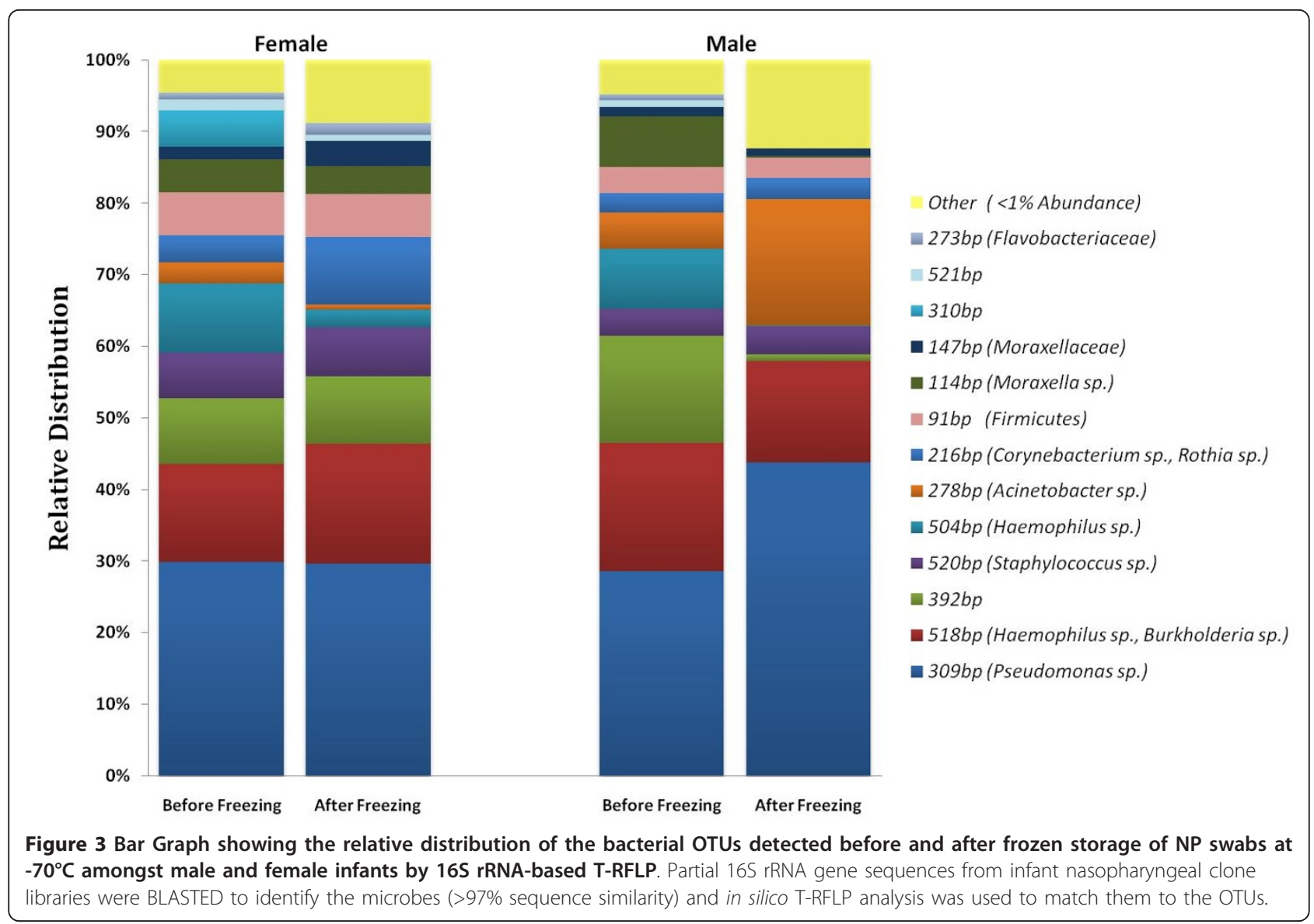

investigation is needed to determine the precise mechanisms by which shifts in microbial community structure occur following frozen storage.

\section{Conclusions}

The potential effects of frozen storage on the composition and relative abundance of microbial populations should not be overlooked with the widespread use of molecular applications in microbial ecology studies.

\section{Acknowledgements}

This work was funded by the Medical Research Council, United Kingdom. We would like to thank the study participants and their parents, the field team and laboratory support group.

\section{Author details}

${ }^{1}$ Bacterial Diseases Programme, Medical Research Council Laboratories (UK), Banjul, The Gambia. 'Department of Infection, Immunity, and Inflammation, University of Leicester, Leicester, UK. ${ }^{3}$ Bill \& Melinda Gates Foundation, Seattle, USA.

\section{Authors' contributions}

$B K, M B, R A A$ and MA proposed the concept and design of this study. BK prepared the clinical samples and performed all the experiments with MA. BK, NIM, DJ and MA performed the data analysis. BK and MA wrote the manuscript with input from all. All authors contributed in discussions and approved the final manuscript.

\section{Competing interests}

The authors declare that they have no competing interests.

Received: 20 August 2010 Accepted: 24 January 2011 Published: 24 January 2011

\section{References}

1. O'Brien KL, Bronsdon MA, Dagan R, Yagupsky P, Janco J, Elliott J, Whitney CG, Yang YH, Robinson LG, Schwartz B, Carlone GM: Evaluation of a medium (STGG) for transport and optimal recovery of Streptococcus pneumoniae from nasopharyngeal secretions collected during field studies. J Clin Microbiol 2001, 39:1021-1024.

2. O'Brien $\mathrm{KL}$, Nohynek $\mathrm{H}$ : Report from a WHO working group: standard method for detecting upper respiratory carriage of Streptococcus pneumoniae. Pediatr Infect Dis J 2003, 22:133-140.

3. Moreno J, Hernandez E, Sanabria O, Castaneda E: Detection and serotyping of Streptococcus pneumoniae from nasopharyngeal samples by PCR-based multiplex assay. J Clin Microbiol 2005, 43:6152-6154.

4. Suomalainen LR, Reunanen $H$, ljas R, Valtonen ET, Tiirola M: Freezing induces biased results in the molecular detection of Flavobacterium columnare. Appl Environ Microbiol 2006, 72:1702-1704.

5. Charalambous BM, Batt SL, Peek AC, Mwerinde H, Sam N, Gillespie SH: Quantitative validation of media for transportation and storage of Streptococcus pneumoniae. J Clin Microbiol 2003, 41:5551-5556.

6. Watson K, Carville K, Bowman J, Jacoby P, Riley TV, Leach AJ, Lehmann D: Upper respiratory tract bacterial carriage in Aboriginal and non-Aboriginal children in a semi-arid area of Western Australia. Pediatr Infect Dis J 2006 25:782-790.

7. Pletz MW, Maus U, Krug N, Welte T, Lode H: Pneumococcal vaccines: mechanism of action, impact on epidemiology and adaption of the species. Int J Antimicrob Agents 2008, 32:199-206. 
8. Cohen R, Levy C, Thollot F, de La Rocque F, Koskas M, Bonnet E, Fritzell B, Varon E: Pneumococcal conjugate vaccine does not influence Staphylococcus aureus carriage in young children with acute otitis media. Clin Infect Dis 2007, 45:1583-1587.

9. Guevara M, Barricarte A, Gil-Setas A, Garcia-Irure JJ, Beristain X, Torroba L, Petit A, Polo Vigas ME, Aguinaga A, Castilla J: Changing epidemiology of invasive pneumococcal disease following increased coverage with the heptavalent conjugate vaccine in Navarre, Spain. Clin Microbiol Infect 2009, 15:1013-1019.

10. Revai K, McCormick DP, Patel J, Grady JJ, Saeed K, Chonmaitree T: Effect of pneumococcal conjugate vaccine on nasopharyngeal bacterial colonization during acute otitis media. Pediatrics 2006, 117:1823-1829.

11. Nichols D, Lewis K, Orjala J, Mo S, Ortenberg R, O'Connor P, Zhao C, Vouros P, Kaeberlein T, Epstein SS: Short peptide induces an "uncultivable" microorganism to grow in vitro. Appl Environ Microbiol 2008, 74:4889-4897.

12. Dethlefsen L, McFall-Ngai M, Relman DA: An ecological and evolutionary perspective on human-microbe mutualism and disease. Nature 2007, 449:811-818

13. von Wintzingerode F, Gobel UB, Stackebrandt E: Determination of microbial diversity in environmental samples: pitfalls of PCR-based rRNA analysis. FEMS Microbiol Rev 1997, 21:213-229.

14. Handelsman J: Metagenomics: application of genomics to uncultured microorganisms. Microbiol Mol Biol Rev 2004, 68:669-685.

15. Huse SM, Dethlefsen L, Huber JA, Welch DM, Relman DA, Sogin ML: Exploring microbial diversity and taxonomy using SSU rRNA hypervariable tag sequencing. PLOS Genet 2008, 4:e1000255.

16. Carrigg C, Rice O, Kavanagh S, Collins G, O'Flaherty V: DNA extraction method affects microbial community profiles from soils and sediment. Appl Microbiol Biotechnol 2007, 77:955-964

17. Grahn N, Olofsson M, Ellnebo-Svedlund K, Monstein HJ, Jonasson J: Identification of mixed bacterial DNA contamination in broad-range PCR amplification of 16S rDNA V1 and V3 variable regions by pyrosequencing of cloned amplicons. FEMS Microbiol Lett 2003, 219:87-91.

18. Huys $G$, Vanhoutte $T$, Joossens M, Mahious AS, De Brandt E, Vermeire $S$, Swings J: Coamplification of eukaryotic DNA with 16S rRNA gene-based PCR primers: possible consequences for population fingerprinting of complex microbial communities. Curr Microbiol 2008, 56:553-557.

19. Muhl H, Kochem AJ, Disque C, Sakka SG: Activity and DNA contamination of commercial polymerase chain reaction reagents for the universal $16 \mathrm{~S}$ rDNA real-time polymerase chain reaction detection of bacterial pathogens in blood. Diagn Microbiol Infect Dis 66:41-49.

20. Petrosino JF, Highlander S, Luna RA, Gibbs RA, Versalovic J: Metagenomic pyrosequencing and microbial identification. Clin Chem 2009, 55:856-866

21. Abdullahi O, Wanjiru E, Musyimi R, Glass N, Scott JA: Validation of nasopharyngeal sampling and culture techniques for detection of Streptococcus pneumoniae in children in Kenya. J Clin Microbiol 2007, 45:3408-3410.

22. Sekar $R$, Kaczmarsky LT, Richardson LL: Effect of freezing on PCR amplification of $16 \mathrm{~S}$ rRNA genes from microbes associated with black band disease of corals. Appl Environ Microbiol 2009, 75:2581-2584.

23. Schutte UM, Abdo Z, Bent SJ, Shyu C, Williams CJ, Pierson JD, Forney LJ: Advances in the use of terminal restriction fragment length polymorphism (T-RFLP) analysis of $16 \mathrm{~S}$ rRNA genes to characterize microbial communities. Appl Microbiol Biotechnol 2008, 80:365-380.

24. Hill PC, Cheung YB, Akisanya A, Sankareh K, Lahai G, Greenwood BM, Adegbola RA: Nasopharyngeal carriage of Streptococcus pneumoniae in Gambian infants: a longitudinal study. Clin Infect Dis 2008, 46:807-814.

25. Takeshita T, Nakano Y, Yamashita Y: Improved accuracy in terminal restriction fragment length polymorphism phylogenetic analysis using a novel internal size standard definition. Oral Microbiol Immunol 2007, 22:419-428.

26. Dicksved J, Floistrup $H$, Bergstrom A, Rosenquist $M$, Pershagen $G$, Scheynius A, Roos S, Alm JS, Engstrand L, Braun-Fahrlander C, von Mutius E, Jansson JK: Molecular fingerprinting of the fecal microbiota of children raised according to different lifestyles. Appl Environ Microbiol 2007, 73:2284-2289.

27. Godden SM, Jansen JT, Leslie KE, Smart NL, Kelton DF: The effect of sampling time and sample handling on the detection of Staphylococcus aureus in milk from quarters with subclinical mastitis. Can Vet J 2002, 43:38-42.
28. Schukken YH, Grommers FJ, Smit JA, Vandegeer D, Brand A: Effect of freezing on bacteriologic culturing of mastitis milk samples. J Dairy Sci 1989, 72:1900-1906.

29. Kaijalainen T, Ruokokoski E, Ukkonen P, Herva E: Survival of Streptococcus pneumoniae, Haemophilus influenzae, and Moraxella catarrhalis frozen in skim milk- tryptone-glucose-glycerol medium. J Clin Microbiol 2004, 42:412-414.

30. Day JG: Cryopreservation of microalgae and cyanobacteria. Methods $\mathrm{Mol}$ Biol 2007, 368:141-151.

31. Principi NM, Marchisio PM, Schito GCM, Mannelli SM, The Ascanius Project Collaborative G: Risk factors for carriage of respiratory pathogens in the nasopharynx of healthy children. Pediatric Infectious Disease Journal 1999, 18:517-523.

32. Mueller S, Saunier K, Hanisch C, Norin E, Alm L, Midtvedt T, Cresci A, Silvi S, Orpianesi C, Verdenelli MC, Clavel T, Koebnick C, Zunft HJ, Dore J, Blaut M: Differences in fecal microbiota in different European study populations in relation to age, gender, and country: a cross-sectional study. Appl Environ Microbiol 2006, 72:1027-1033.

33. Dagan R: Serotype replacement in perspective. Vaccine 2009, 27(Suppl 3): C22-24.

34. Lipsitch M: Vaccination against colonizing bacteria with multiple serotypes. Proc Natl Acad Sci USA 1997, 94:6571-6576.

35. Li M, Wang B, Zhang M, Rantalainen M, Wang S, Zhou H, Zhang $Y$, Shen J, Pang X, Wei H, Chen Y, Lu H, Zuo J, Su M, Qiu Y, Jia W, Xiao C, Smith LM, Yang S, Holmes E, Tang H, Zhao G, Nicholson JK, Li L, Zhao L: Symbiotic gut microbes modulate human metabolic phenotypes. Proc Natl Acad Sci USA 2008, 105:2117-2122.

36. Nelson KE, Weinstock GM, Highlander SK, Worley KC, Creasy HH, Wortman JR, Rusch DB, Mitreva M, Sodergren E, Chinwalla AT, Feldgarden M, Gevers D, Haas BJ, Madupu R, Ward DV, Birren BW, Gibbs RA, Methe B, Petrosino JF, Strausberg RL, Sutton GG, White OR, Wilson RK, Durkin S, Giglio MG, Gujja S, Howarth C, Kodira CD, Kyrpides N, Mehta T, et al: A catalog of reference genomes from the human microbiome. Science 2010, 328:994-999.

Pre-publication history

The pre-publication history for this paper can be accessed here: http://www.biomedcentral.com/1472-6890/11/2/prepub

doi:10.1186/1472-6890-11-2

Cite this article as: Kwambana et al: Differential effects of frozen storage on the molecular detection of bacterial taxa that inhabit the nasopharynx. BMC Clinical Pathology 2011 11:2.

\section{Submit your next manuscript to BioMed Central and take full advantage of:}

- Convenient online submission

- Thorough peer review

- No space constraints or color figure charges

- Immediate publication on acceptance

- Inclusion in PubMed, CAS, Scopus and Google Scholar

- Research which is freely available for redistribution

Submit your manuscript at www.biomedcentral.com/submit
C Biomed Central 